\title{
H2A O-GlcNAcylation at serine 40 functions genomic protection in association with acetylated $\mathrm{H} 2 \mathrm{AZ}$ or $\mathrm{\gamma H} 2 \mathrm{AX}$
}

Koji Hayakawa ${ }^{1 \dagger}$ (10, Mitsuko Hirosawa ${ }^{1 \dagger}$, Ruiko Tani ${ }^{1}$, Chikako Yoneda', Satoshi Tanaka ${ }^{1}$ and Kunio Shiota ${ }^{12^{*}}$

\begin{abstract}
Background: We have previously reported a novel O-GlcNAc modification at serine 40 (S40) of H2A (H2AS40Gc). S40-type H2A isoforms susceptible to O-GlcNAcylation are evolutionarily new and restricted to the viviparous animals; however, the biological function of H2AS40GC is largely unknown. H2A isoforms are consisted of S40 and alanine 40 (A40) type and this residue on H2A is located in the L1 of the globular domain, which is also known as a variable portion that distinguishes between the canonical and non-canonical H2A variants. In this study, by considering the similarity between the S40-type H2A and histone H2A variants, we explored the function of H2AS40Gc in mouse embryonic stem cells (mESCs).

Results: We found several similarities between the S40-type $\mathrm{H} 2 \mathrm{~A}$ isoforms and histone $\mathrm{H} 2 \mathrm{~A}$ variants such $\mathrm{H} 2 \mathrm{AZ}$ and $\mathrm{H} 2 \mathrm{AX}$. mRNA of S40-type $\mathrm{H} 2 \mathrm{~A}$ isoforms ( $\mathrm{H} 2 \mathrm{~A} 1 \mathrm{~N}$ and $\mathrm{H} 2 \mathrm{~A} 3$ ) had a poly $(\mathrm{A})$ tail and was produced throughout the cell cycle in contrast to that of A40-type. Importantly, H2AS40Gc level increased owing to chemical-induced DNA damage, similar to phosphorylated H2AX ( $(\mathrm{H} 2 \mathrm{AX})$ and acetylated $\mathrm{H} 2 \mathrm{AZ}$ (AcH2AZ). H2AS40Gc was accumulated at the restricted area ( $\pm 1.5 \mathrm{~kb}$ ) of DNA damage sites induced by CRISPR/CAS9 system in contrast to accumulation of $\gamma \mathrm{H} 2 \mathrm{AX}$, which was widely scattered. Overexpression of the wild-type (WT) H2A3, but not the S40 to A40 mutation (S40A-mutant), protected the mESC genome against chemical-induced DNA damage. Furthermore, $3 \mathrm{~h}$ after the DNA damage treatment, the genome was almost recovered in WT mESCs, whereas the damage advanced further in the S40A-mutant mESCs, suggesting functions of H2AS40Gc in the DNA repair mechanism. Furthermore, the S40A mutant prevented the accumulation of the DNA repair apparatus such as DNA-PKcs and Rad51 at the damage site. Co-immunoprecipitation experiment in WT and S40A-mutant mESCs revealed that H2AS40Gc physiologically bound to $\mathrm{AcH} 2 \mathrm{AZ}$ at the initial phase upon DNA damage, followed by binding with $\mathrm{H} 2 \mathrm{AX}$ during the DNA damage repair process.
\end{abstract}

Conclusions: These data suggest that H2AS40Gc functions to maintain genome integrity through the DNA repair mechanism in association with $\mathrm{AcH} 2 \mathrm{AZ}$ and $\mathrm{\gamma H} 2 \mathrm{AX}$.

Keywords: O-GlcNAcylation, Histone modification, Canonical histone, Histone variant, DNA damage, DNA repair

\section{Background}

$O$-linked $\beta$ - $N$-acetylglucosamine (O-GlcNAc) modifications occur at serine (Ser) or threonine $(\mathrm{Thr})$ residues

\footnotetext{
*Correspondence: ashiota@mail.ecc.u-tokyo.ac.jp; ashiota@aoni.waseda.jp ${ }^{\dagger}$ Koji Hayakawa and Mitsuko Hirosawa contributed equally to this work ${ }^{1}$ Laboratory of Cellular Biochemistry, Department of Animal Resource Sciences/Veterinary Medical Sciences, The University of Tokyo,

Tokyo 113-8657, Japan

Full list of author information is available at the end of the article
}

in a number of cytosolic and nuclear proteins including transcription, stem cell, and epigenetic factors as well as histones [1-5]. The Ser or Thr residue is also the site of phosphorylation in various proteins, and a role in the competition between $O$-GlcNAcylation and phosphorylation has been postulated [3]. To date, O-GlcNAcylation on various histones has been reported and the several biological activities have been postulated [6-12]. For example, O-GlcNAcylation at histone H2B serine 112 
(H2BS112) is reportedly linked to transcriptional activation via the promotion of $\mathrm{H} 2 \mathrm{~B}$ ubiquitination [9].

We recently reported a novel $O$-GlcNAc modification at serine 40 (S40) of some H2A isoforms (H2AS40Gc) [13]. Distinct from other histone modifications, H2AS40Gc is restricted to viviparity-specific H2A isoforms. In mammals, there are multiple canonical histone $\mathrm{H} 2 \mathrm{~A}$ isoforms consisting of isoforms with $\mathrm{S} 40$ and alanine 40 (A40), whereas non-mammalian species harbor only A40-type H2A members. Thus, the A40 type seems to be a prototype of $\mathrm{H} 2 \mathrm{~A}$, and S40-type $\mathrm{H} 2 \mathrm{~A}$ isoforms, which are susceptible to O-GlcNAcylation, are evolutionarily new. In our previous study, ChIP-seq analysis revealed that H2AS40Gc is predominantly distributed in genic regions and is associated with gene expression in mouse trophoblast stem cells [13]. However, the biological functions of H2AS40Gc are poorly understood.

Histones are classified into two types, canonical histones and histone variants (non-canonical histones), based on the similarity of the amino acid sequences and several other criteria [14-21]. Canonical histones are encoded as gene clusters and are synthesized at the $\mathrm{S}$ phase of the cell cycle [14, 16-19]. In contrast, each histone variant is encoded alone on other chromosomes and produced in a cell cycle-independent manner [20]. Moreover, mRNA of canonical histones has a unique 3'-stemloop structure instead of a poly(A) tail, whereas mRNA of histone variants has a poly(A) tail $[14,20]$. The functions of histone variants have been studied well, e.g., H2AX and $\mathrm{H} 2 \mathrm{AZ}$ have a role in repairing damaged DNA [14, 21-29].

The site of $O$-GlcNAcylation at S40 of H2A is located in the L1 site of the globular domain where two histone $\mathrm{H} 2 \mathrm{~A} / \mathrm{H} 2 \mathrm{~B}$ dimers associate with each other in the nucleosome (Fig. 1a) [16, 21, 30-32]. L1 is also referred to as a variable portion that distinguishes between canonical and non-canonical $\mathrm{H} 2 \mathrm{~A}$ variants such as $\mathrm{H} 2 \mathrm{AX}$ and $\mathrm{H} 2 \mathrm{AZ}$ (Fig. 1b) $[16,22]$. The structure of L1 with A40/S40 or $O$-GlcNAcylated S40 may contribute to the production of a diverse nucleosome with $\mathrm{H} 2 \mathrm{~A}$ histone variants. Thus, discovering $\mathrm{H} 2 \mathrm{AS} 40 \mathrm{Gc}$ prompted us to explore whether the S40-type H2A isoforms are expressed as ordinary canonical histones or as unique histone-like variants and whether there are structural differences in the $3^{\prime}$ tail of the mRNA between S40- and A40-type H2A. Furthermore, by considering the analogy of S40-type H2A isoforms and histone variants, the function of H2AS40Gc can be studied. Here, we show that some genes for S40type $\mathrm{H} 2 \mathrm{~A}$, susceptible to $\mathrm{O}$-GlcNAcylation, are expressed in a cell cycle-independent manner, similar to that of histone variants. In addition, we revealed that H2AS40Gc is responsive to DNA damage and plays a role in DNA damage repair (DDR) in association with phosphorylated $\mathrm{H} 2 \mathrm{AX}(\gamma \mathrm{H} 2 \mathrm{AX})$ and acetylated H2AZ (AcH2AZ).

\section{Results}

Gene expression of H2AS40 isoforms in a cell cycle-independent manner

There are 18 canonical histone $\mathrm{H} 2 \mathrm{~A}$ isoforms, of which thirteen S40 and five A40 types are present in mouse (Fig. 1c). Seven S40 types and one A40 type are located on gene cluster 1, whereas no S40 types are located on cluster 2. Of note, the H2A3 gene (Hist3h2a) is solitary in the genome similar to histone variants.

We investigated the expression profile of $14 \mathrm{H} 2 \mathrm{~A}$ isoforms, including $\mathrm{S} 40$ and $\mathrm{A} 40$ types, during cell cycle by RT-qPCR using specific primer sets (Additional file 1: Table S1) in mouse embryonic stem cells (mESCs) synchronized by combinatorial treatment with thymidine and nocodazole (Fig. 1d, left). RT-qPCR analysis revealed expression of the H2AX-encoding gene (H2afx) throughout the cell cycle, similar to a previous study [20]. The H2AZ-encoding gene ( H2afz) also showed cell cycleindependent expression, whereas the expression of other variants (H2afy and H2afy2) decreased during the G1 phase.

Intriguingly, Hist $3 h 2 a$ (encoding the canonical histone H2A3) was constantly expressed throughout the cell cycle (Fig. 1d, left) similar to H2afx. Other members such as Hist1h2an (S40 type), Hist2h2aa1 (A40 type) were also expressed regardless of the cell cycle. Remaining members of H2A were expressed in a typical S-phase-dependent pattern. Thus, some S40-type H2A isoforms were produced throughout the cell cycle. Western blotting analysis of synchronized mESCs showed that H2AS40Gc was constantly observed throughout the cell cycle in contrast to histone $\mathrm{H} 3$ phosphorylation at $\mathrm{S} 10$ (H3S10Phos; Fig. 1e).

To investigate the structure of the $3^{\prime}$ tail of H2A mRNA, we prepared cDNA synthesized by oligo $(\mathrm{dT})$ primers or random hexamers. Almost all of the $\mathrm{H} 2 \mathrm{~A}$ members were highly expressed using the cDNA synthesized by random hexamers (Fig. 1d, right), while their expression levels were low or undetectable in the cDNA using oligo(dT) primers (Fig. 1d, middle). These data support the findings of previous reports indicating that genes encoding histone $\mathrm{H} 2 \mathrm{~A}$ that are primarily expressed at the $\mathrm{S}$ phase harbor the $3^{\prime}$-stem-loop structure instead of a poly(A) structure $[14,19,20]$. By contrast, RT-qPCR using the cDNA prepared by oligo $(\mathrm{dT})$ primers confirmed that $H 2 a f x$ and $H 2 a f z$ mRNA had a poly(A) structure (Fig. 1d, middle). Interestingly, the mRNAs for Hist1h2an, Hist2h2aa1, and Hist $3 h 2 a$, but not other mRNAs for remaining members, could be detected by the oligo $(\mathrm{dT})$ based cDNA.

Taken together, these data clarify that some H2A isoforms (Hist1h2an, Hist2h2aal, and Hist3h2a) are expressed independent of the cell cycle and have a poly(A) 


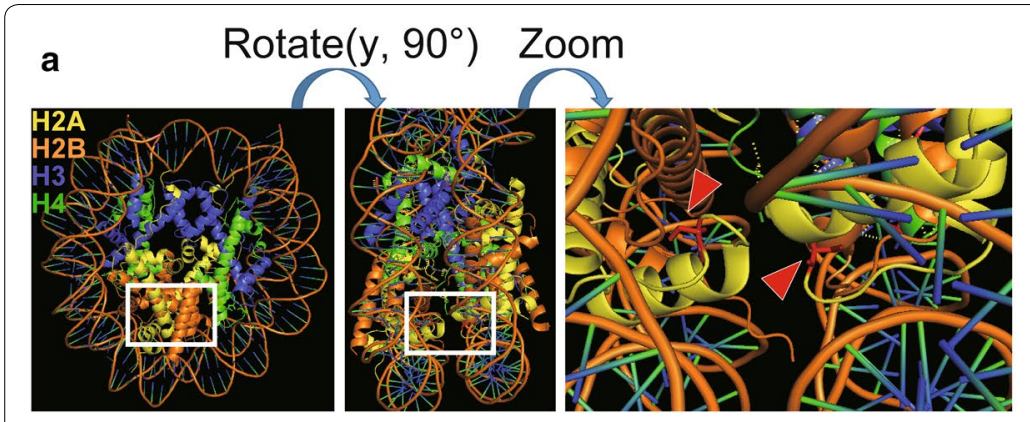

\begin{tabular}{|c|c|c|c|}
\hline Protein & Gene & $\begin{array}{c}\text { AA residue } \\
\text { at } 40\end{array}$ & $\begin{array}{l}\text { Gene } \\
\text { Cluster }\end{array}$ \\
\hline $\mathrm{H} 2 \mathrm{~A} 1 \mathrm{~A}$ & Hist1h2aa & Ala & \multirow{13}{*}{1} \\
\hline $\mathrm{H} 2 \mathrm{~A} 1 \mathrm{~B}$ & Hist1h2ab & Ser & \\
\hline $\mathrm{H} 2 \mathrm{~A} 1 \mathrm{C}$ & Hist1h2ac & Ser & \\
\hline H2A1D & Hist1H2ad & Ser & \\
\hline $\mathrm{H} 2 \mathrm{~A} 1 \mathrm{E}$ & Hist1h2ae & Ser & \\
\hline $\mathrm{H} 2 \mathrm{~A} 1 \mathrm{~F}$ & Hist1h2af & Ser & \\
\hline $\mathrm{H} 2 \mathrm{~A} 1 \mathrm{G}$ & Hist1h2ag & Ser & \\
\hline $\mathrm{H} 2 \mathrm{~A} 1 \mathrm{H}$ & Hist1h2ah & Ser & \\
\hline H2A1I & Hist1h2ai & Ser & \\
\hline $\mathrm{H} 2 \mathrm{~A} 1 \mathrm{~K}$ & Hist1h2ak & Ser & \\
\hline $\mathrm{H} 2 \mathrm{~A} 1 \mathrm{~N}$ & Hist1h2an & Ser & \\
\hline $\mathrm{H} 2 \mathrm{~A} 10$ & Hist1h2ao & Ser & \\
\hline $\mathrm{H} 2 \mathrm{~A} 1 \mathrm{P}$ & Hist1h2ap & Ser & \\
\hline $\mathrm{H} 2 \mathrm{~A} 2 \mathrm{~A} 1$ & Hist2h2aa1 & Ala & \multirow{4}{*}{2} \\
\hline $\mathrm{H} 2 \mathrm{~A} 2 \mathrm{~A} 2$ & Hist2h2aa2 & Ala & \\
\hline $\mathrm{H} 2 \mathrm{~A} 2 \mathrm{~B}$ & Hist2h2ab & Ala & \\
\hline $\mathrm{H} 2 \mathrm{~A} 2 \mathrm{C}$ & Hist2h2ac & Ala & \\
\hline $\mathrm{H} 2 \mathrm{~A} 3$ & Hist3h2a & Ser & 3 \\
\hline
\end{tabular}

b

$$
\begin{aligned}
& \mathrm{AcHN} a \mathrm{aN}, \alpha 1, \alpha 2-\alpha 3-a C-\mathrm{COO}^{-} \\
& \left.\begin{array}{l}
\text { H2A (A40) } \\
\text { H2A...NYAE (S40) .......... NYSE...... }
\end{array}\right] \text { Canonical } \\
& \text { H2AX .....HYAE..... } 7 \text { Non- } \\
& \text { H2AZ.1 .....TSHG..... canonical }
\end{aligned}
$$

c

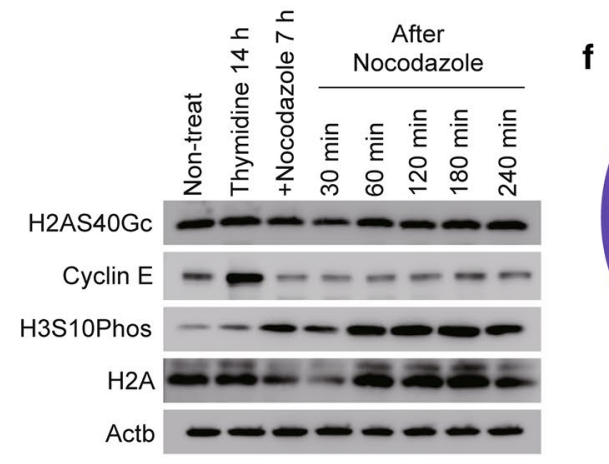

d

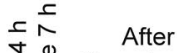

$\checkmark \frac{0}{0}$ Nocodazole

(1)

$\stackrel{0}{\mathrm{~N}}$

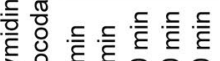

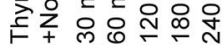

Hist1h2aa

Hist1h2ab

Hist1h2ad

Hist1h2af

Hist1h2ag

Hist1h2ah

Hist1h2ak

Hist1h2an

Hist1h2ao

Histzh $2 a \bar{a} \overline{1}$

Hist2h2aa2

Hist2h2ab

Hist2h2ac

Hist $3 h 2 a$

H2afx

H2afz

H2afy

H2afy2

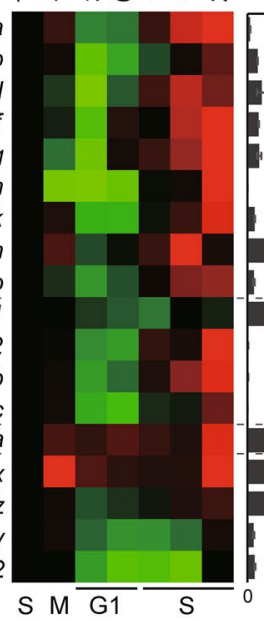

Relative expression

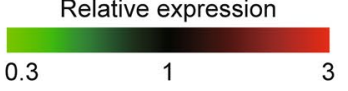

\section{3}

cDNA synthesis

by oligo(dT) by random hexamer

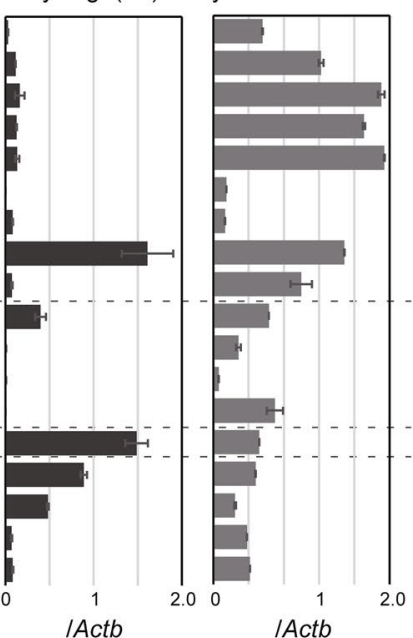

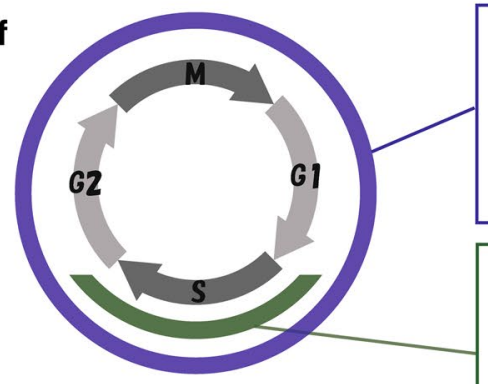

Cell cycle-independent

Canonical:

Hist1h2an, Hist2h2aa1, Hist3h2a.

Variant: H2afx, H2afz

\section{S phase-dependent}

Canonical:

Hist1h2a 2k, 2o, Hist2h2aa1 2ac.

Variant: H2afy, H2afy2.

Fig. 1 Cell cycle-independent H2AS40Gc production. a Three-dimensional reconstruction map of core histones. Arrowheads indicate residue 40 of H2A. b Sequence diversity of L1 loop region in H2A. c List of canonical H2As in mice. This list is based on Refseq database (mouse mm9). d Left, expression level of H2A-coding genes in synchronized mESCs. Values are expressed as relative to that of thymidine-treated (14 h) mESCs, which is set as 1. Right, expression level of mRNA for H2A-coding genes using CDNA synthesized using oligo(dT) primer or random hexamer (RH) in non-synchronized mESCs. Values are normalized by Actb expression. e H2AS40Gc level in synchronized mESCs. Cyclin E and phosphorylated H3S10 (H3S1OPhos) were used to determine cell cycle phases. Actb was used as the internal control. f Summary of canonical and variant $\mathrm{H} 2 \mathrm{~A}$ gene expression through cell cycle 
structure similar to genes for $\mathrm{H} 2 \mathrm{~A}$ variants such as $\mathrm{H} 2 \mathrm{afx}$ and $\mathrm{H} 2 \mathrm{afz}$ (Fig. 1f). Among the thirteen S40-type H2A members, $\mathrm{H} 2 \mathrm{~A} 3$ and $\mathrm{H} 2 \mathrm{~A} 1 \mathrm{~N}$ are the only members that were expressed in a cell cycle-independent manner and their mRNA contained a poly(A) tail structure.

\section{DNA damage induced H2AS40Gc foci overlapping with $\gamma \mathrm{H} 2 \mathrm{AX}$ and $\mathrm{AcH} 2 \mathrm{AZ}$}

We previously observed that H2AS40Gc can be recognized as dotted foci in the nucleus of mouse trophoblast stem cells, germ cells, and ESCs with immunofluorescence (IF) analysis [13]. Considering that the formation of dotted foci is a characteristic of $\gamma \mathrm{H} 2 \mathrm{AX}$ and $\mathrm{AcH} 2 \mathrm{AZ}$ $[16,21-29], H 2 A S 40 G c$ may have a similar function to H2AX and H2AZ. Since $\gamma \mathrm{H} 2 \mathrm{AX}$ and AcH2AZ are involved in maintaining genome integrity and the DDR process, we next investigated the response of H2AS40Gc against DNA damage.

IF assay confirmed that H2AS40Gc was visualized as dotted foci in mESCs (Fig. 2a). When the cells were treated for $4 \mathrm{~h}$ with topoisomerase inhibitors, camptothecin (CPT) or etoposide (ETP), IF revealed an increase in the number of H2AS40Gc foci (Fig. 2a, b). In parallel, the number of $\gamma \mathrm{H} 2 \mathrm{AX}$ foci also increased following the topoisomerase inhibitor treatment (Fig. 2a). The overlapping of H2AS40Gc foci with $\gamma \mathrm{H} 2 \mathrm{AX}$ foci increased to 11.3 and $22.6 \%$ in CTP- and ETP-treated cells, respectively, compared to those in non-stimulated control cells (Fig. 2a, c).

More than 19\% of the H2AS40Gc foci overlapped with $\mathrm{AcH} 2 \mathrm{AZ}$ in non-treated mESCs (Fig. 2d, e). CTP and ETP treatments caused an increase in the AcH2AZ signals. The foci of H2AS40Gc overlapped with AcH2AZ foci at 17.6 and $7.6 \%$ in CTP and ETP treatments, respectively. Thus, overlapping of $\mathrm{H} 2 \mathrm{AS} 40 \mathrm{Gc}$ with $\mathrm{AcH} 2 \mathrm{AZ}$ is reciprocal to that with $\gamma \mathrm{H} 2 \mathrm{AX}$ before and after the treatments. Western blotting analysis of nuclear fractions revealed that H2AS40Gc levels started increasing $60 \mathrm{~min}$ after the initiation of ETP treatment, whereas $\gamma \mathrm{H} 2 \mathrm{AX}$ levels increased after $15 \mathrm{~min}$ and then increased gradually (Fig. 2f, g). After 90 and 180 min of the treatment, levels of $\gamma \mathrm{H} 2 \mathrm{AX}$ and H2AS40Gc, respectively, reached at high levels (Fig. 2g). Nuclear accumulation of AcH2AZ was high $15 \mathrm{~min}$ after ETP treatment and reached the maximum level at $30 \mathrm{~min}$. The high level of $\mathrm{AcH} 2 \mathrm{AZ}$ was maintained until 90-120 min when H2AS40Gc accumulation started, and then reduced to the basal level after 120 min (Fig. 2g).

Taken together, this is the first report to demonstrate that induction of H2AS40Gc is responsive to the DNA damages. The nuclear accumulation of H2AS40Gc, $\gamma \mathrm{H} 2 \mathrm{AX}$, and $\mathrm{AcH} 2 \mathrm{AZ}$ and their co-localization exhibit dramatic changes during the DNA damage responses.

\section{Accumulation of $\mathrm{H} 2 \mathrm{AS} 40 \mathrm{Gc}$ at sites of DNA damage induced by CRISPR/CAS9 system}

To confirm H2AS40Gc localization at the genomic damage loci, we induced locus-specific DNA damage by using CRISPR/CAS9 system, wherein the guide RNA (gRNA) was designed for the two sites on exon 9 of the Tet 2 gene on chromosome 3 (Fig. 3a) and the intergenic area on chromosome 13 (Fig. 3e). ChIP signals were calculated as ChIP DNA/input DNA and expressed as fold enrichment relative to the uncut (mESCs expressing guide RNA and nuclease-deficient CAS9). Using $\gamma \mathrm{H} 2 \mathrm{AX}$ as the DNA damage marker, the CRISPR/CAS9-induced genome damage on chromosomes 3 and 13 could be detected after $16 \mathrm{~h}$ and continued until $24 \mathrm{~h}$ after the transfection (Fig. 3b, f). The increase in H2AS40Gc localization was parallel to that of $\gamma \mathrm{H} 2 \mathrm{AX}$ in the time-course study.

At $16 \mathrm{~h}$ after transfection, distribution of $\gamma \mathrm{H} 2 \mathrm{AX}$ was confirmed in the relatively wide range of $\pm 50 \mathrm{~kb}$ around the DNA damage sites, as previously reported [24, 27], on both chromosomes 3 and 13 (Fig. 3c, g). H2AS40Gc was also observed at the damaged sites. Interestingly, however, H2AS40Gc localized within a narrow range within the $\pm 1.5 \mathrm{~kb}$ band from the DNA damage site. At $24 \mathrm{~h}$ after transfection, accumulation of H2AS40Gc was observed within the narrow area, whereas the occupancy band of $\gamma \mathrm{H} 2 \mathrm{AX}$ was more than $\pm 50 \mathrm{~kb}$ on the cutting sites (Fig. 3d, h). Disappearance of AcH2AZ occurred at the DNA damage sites earlier than the disappearance of H2AS40Gc and $\gamma \mathrm{H} 2 \mathrm{AX}$ at $24 \mathrm{~h}$.

Thus, we confirmed the accumulation of H2AS40Gc at the DNA damage sites. Interestingly, H2AS40Gc did not expand its territory for the DDR process as observed in the case of $\gamma \mathrm{H} 2 \mathrm{AX}$ and was retained at the center of the DNA damage regardless of genic and intergenic regions.

\section{Genomic protection and DDR by H2AS40Gc}

To verify the hypothesis of H2AS40Gc functioning in the maintenance of genome integrity, we prepared mESCs stably overexpressing either $3 \times$ FLAG-tagged wildtype H2A3 (H2A3-WT mESC; two lines \#1 and \#2) or $3 \times$ FLAG-tagged mutant in which serine at position 40 was substituted with alanine (S40A-mutant mESCs; two lines \#1 and \#2; Fig. 4). Flag-fused H2A3 could be $O$-GlcNAcylated in H2A3-WT mESCs, whereas no $O$-GlcNAcylation was observed in S40A-mutant mESCs (Fig. 4a, left). O-GlcNAc level of endogenous H2A was reduced to approximately 60 and 30\% in H2A3-WT and S40A-mutant mESCs, respectively, compared to that in control mESCs expressing Flag-only (Fig. 4a, right). Consequently, total level of O-GlcNAcylated H2AS40 consisting of endogenous $\mathrm{H} 2 \mathrm{~A}$ and the exogenous Flag$\mathrm{H} 2 \mathrm{~A} 3$ was much lower in the S40A-mutant mESCs than 


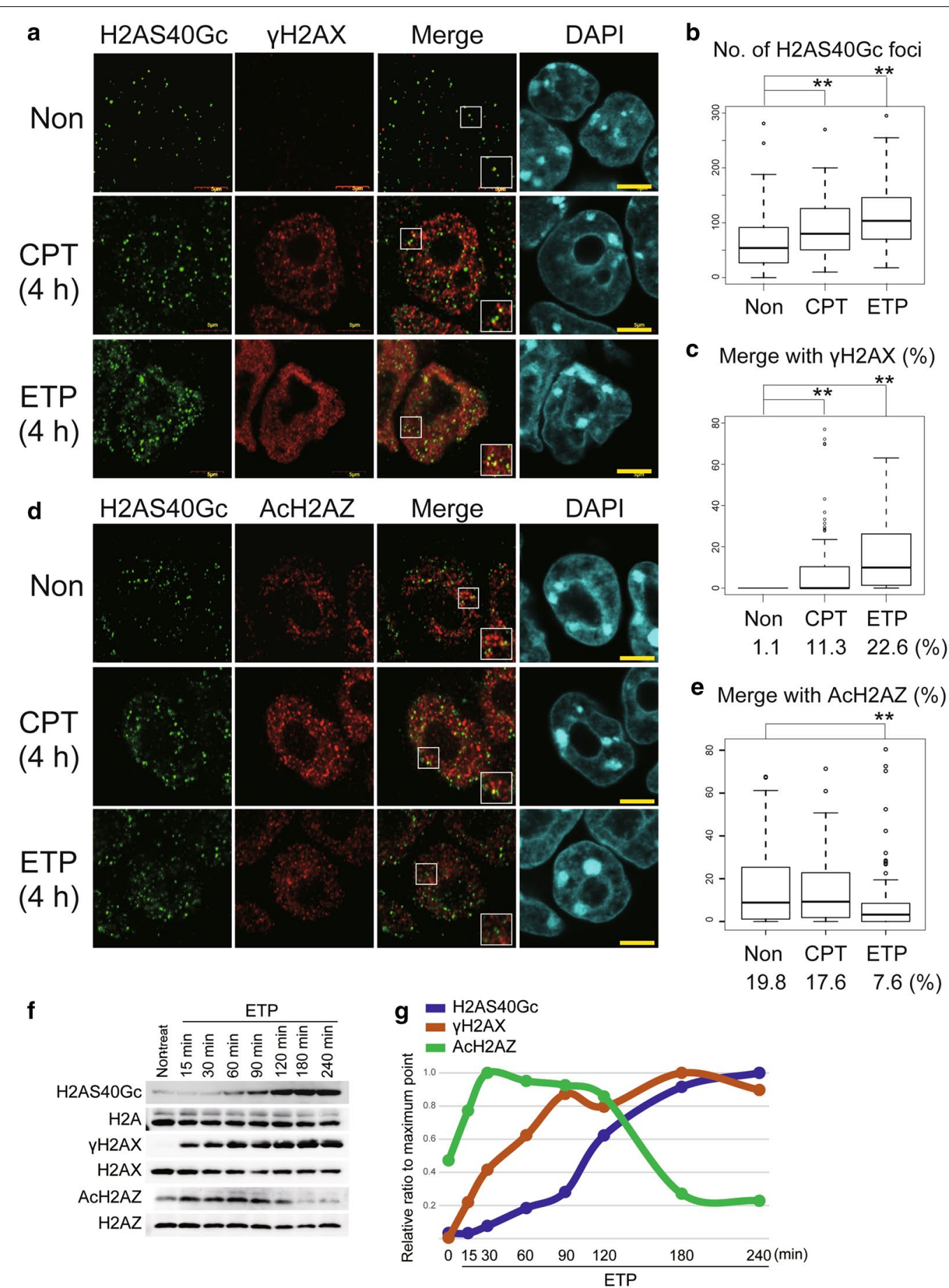

Fig. $2 \mathrm{H} 2 \mathrm{AS} 40 \mathrm{GC}$ is responsive to DNA damages. a-e Immunofluorescence (IF) images of H2AS40Gc, $\mathrm{YH} 2 \mathrm{AX}$, and AcH2AZ in mESCs treated with camptothecin (CPT) and etoposide (ETP). The lower right box in the photo is the zoomed white box in the nucleus. Bars $=5 \mu \mathrm{m}$. Measurement of the number of H2AS40Gc foci (b) and co-localization of H2AS4OGc with $\mathrm{YH} 2 \mathrm{AX}$ (c) or AcH2AZ (e) in nuclei of mESCs treated with CPT and ETP ${ }^{* *} p<0.01 . \mathbf{f}, \mathbf{g}$ Time course of accumulation of H2AS40Gc, $\gamma \mathrm{H} 2 \mathrm{AX}$, and AcH2AZ proteins in ETP-treated mESCs. The graph was plotted from band intensities of $\mathbf{f}$ calculated by the ImageJ software $(\mathbf{g})$. Values of $\mathrm{H} 2 \mathrm{AS} 40 \mathrm{Gc}, \mathrm{\gamma H} 2 \mathrm{AX}$, and $\mathrm{AcH} 2 \mathrm{AZ}$ were normalized to the intensity of a-H2A, $-\mathrm{H} 2 \mathrm{AX}$, and $-\mathrm{H} 2 \mathrm{AZ}$, respectively, and expressed as a ratio relative to the maximum 


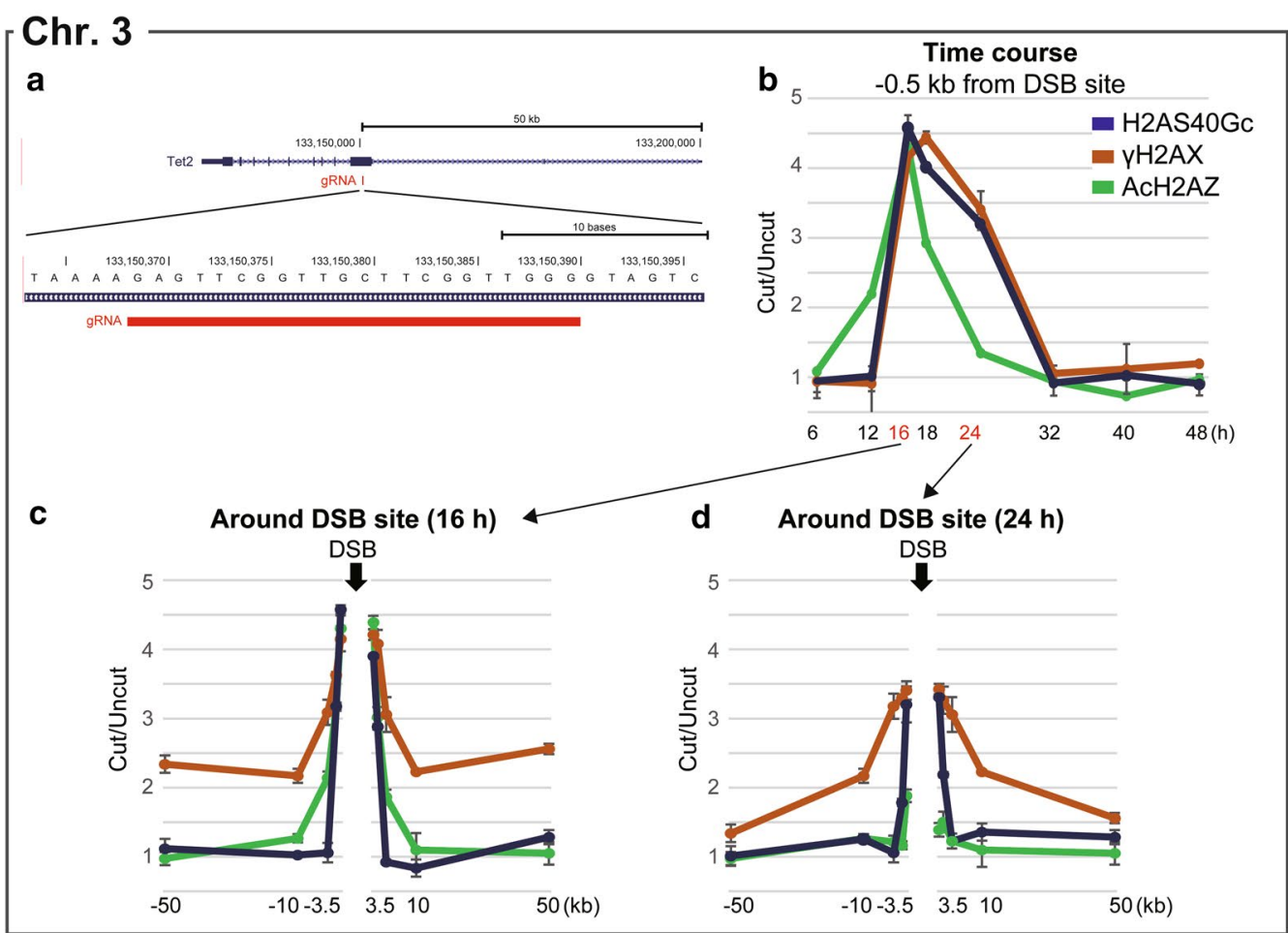

Chr. 13

e

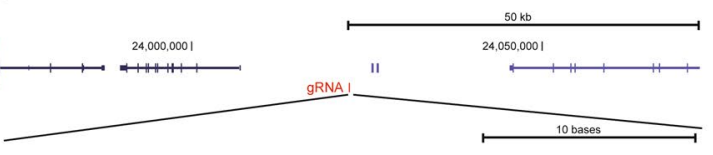

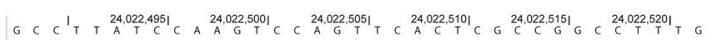

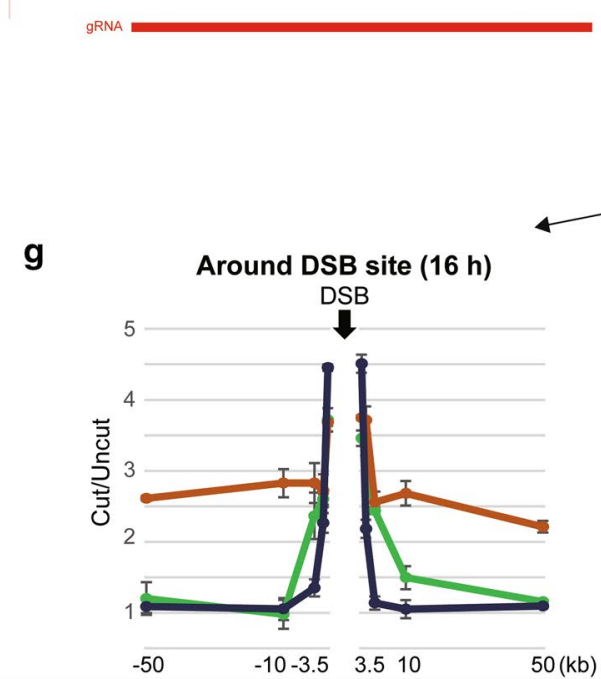

Time course

Time course
$.5 \mathrm{~kb}$ from DSB site

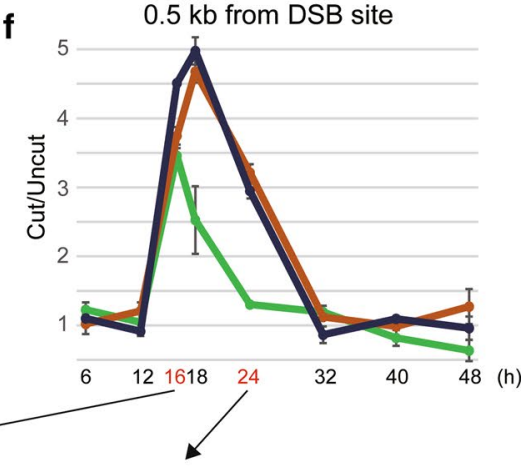

h Around DSB site $(24 \mathrm{~h})$

DSB

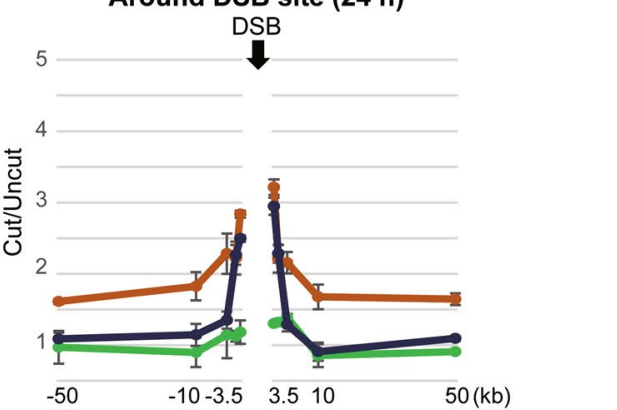

Fig. $3 \mathrm{H} 2 \mathrm{AS} 40 \mathrm{Gc}$ in sites of DNA damages. a-h Level of H2AS40GC, $Y \mathrm{H} 2 \mathrm{AX}$, and ACH2AZ around the damaged DNA site induced by the CRISPR/ CAS9 system. gRNA-target regions were selected at gene-body (chromosome 3) (a) and intergenic region (chromosome 13) (e). Level of H2AS40Gc and $\mathrm{YH} 2 \mathrm{AX}$ at $-0.5 \mathrm{~kb}$ from damaged DNA site on chromosome $3(\mathbf{b})$ and $0.5 \mathrm{~kb}$ from the damaged DNA site on chromosome 13 (f). ChIP signals were calculated as ChIP DNA/Input DNA and expressed as fold enrichment relative to the uncut (mESCs expressing guide RNA and nucleasedeficient CAS9). Values indicate mean $\pm \mathrm{SD}(n=3)$. Enrichment of H2AS40Gc and $\gamma \mathrm{H} 2 \mathrm{AX}$ around the DNA damage site on chromosome 3 (c, $\mathbf{d})$ and chromosome $13(\mathbf{g}, \mathbf{h})$ induced using CRISPR/CAS9, at 16 and $24 \mathrm{~h}$ after transfection. Values indicate mean $\pm \mathrm{SD}(n=3)$. DSB, double-strand DNA break 
those in H2A3-WT mESCs (Fig. 4a, right). Thus, the set of H2A3-WT and S40A-mutant mESCs can be used for mechanistic analysis of H2AS40Gc.

Therefore, we evaluated the genome damage by treatment with ETP (Fig. 4b) in H2A3-WT and S40A-mutant mESCs. In these cells, ETP treatment for $4 \mathrm{~h}$ caused fragmentation of DNA. The level of DNA fragmentation was significantly less in the H2A3-WT mESCs compared to that in S40A-mutant mESCs (Fig. 4b, c), suggesting that H2AS40Gc functions to protect the genome against DNA damage. Then, we checked the cell viability of the WTand S40A-mutant mESCs in the presence of ETP or bleomycin (BLM), a genotoxic anticancer reagent (Fig. 4d). H2A3-WT mESCs showed more resistance to the genotoxic reagents compared to the S40A-mutant mESCs.

We also investigated genome recovery after ETPinduced DNA damages (Fig. 4b, c). In H2A3-WT mESCs, fragmented DNA reduced evidently $3 \mathrm{~h}$ after cessation of ETP treatment. In contrast, DNA fragmentation advanced further in the S40A-mutant mESCs, suggesting that $\mathrm{H} 2 \mathrm{AS} 40 \mathrm{Gc}$ has a role in DDR.

\section{Accumulation of DNA-PKcs and Rad51 requires $\mathrm{H} 2 \mathrm{AS} 40 \mathrm{Gc}$ in DDR}

Various DDR-related proteins have been identified that play critical roles in the DDR process [33, 34]. For example, DNA-PKcs works at the first step of the homologous recombination process and Rad51 works at the later step of non-homologous end-joining process. ETP treatment for $4 \mathrm{~h}$ caused an increase in DNA-PKcs and Rad51 in mESCs (Additional file 1: Figure S1). The overlapping of H2AS40Gc foci with DNA-PKcs and Rad51 foci increased to 15.5 and $25.4 \%$ by ETP treatment, respectively (Additional file 1: Figure S1).

To get insights into the mechanism of DDR by H2AS40Gc, we next investigated whether DNA-PKcs and Rad51 were induced by ETP in S40A-mESCs. The elevation in H2AS40Gc foci with ETP treatment could be confirmed in H2A3-WT mESCs (Fig. 5a). This change reflected the total $\mathrm{S} 40 \mathrm{O}-\mathrm{GlcNA}$ cylation of endogenous $\mathrm{H} 2 \mathrm{~A}$ and exogenous Flag-H2A3 (Fig. 4a). In the S40Amutant mESCs, the number of H2AS40Gc foci was quite low in the non-treated condition and did not increase by ETP treatment (Fig. 5a). ETP treatment caused an increase in the dotted foci of DNA-PKcs and Rad51 in H2A3-WT mESCs. Importantly, such an increase in DNA-PKcs and Rad51 foci by ETP treatment was not observed in the S40A-mutant mESCs (Fig. 5b, c).

In western blotting analysis, $\gamma \mathrm{H} 2 \mathrm{AX}$ increased similarly in both H2A3-WT and S40A-mutant mESCs in response to ETP treatment, and the level was maintained $3 \mathrm{~h}$ after the recovery period (Additional file 1: Figure S2). The level of H2AX was constant with or without ETP in both H2A3-WT and S40A-mutant cells, suggesting that phosphorylation at S139 of H2AX was not affected by the decreasing $\mathrm{O}$-GlcNAcylation of S40 of H2A. Slight increase in AcH2AZ was observed in S40A-mutant mESCs in response to ETP treatment.

Taken together, these data suggest that H2AS40 is required for the induction of DDR factors such as DNAPKcs and Rad51 without affecting phosphorylation of H2AX.

\section{H2AS40Gc associates with AcH2AZ and $\mathrm{\gamma H} 2 \mathrm{AX}$ during DDR process}

To determine the direct association of H2AS40Gc with $\mathrm{AcH} 2 \mathrm{AZ}$ or $\mathrm{\gamma H} 2 \mathrm{AX}$, immunoprecipitation (IP) using anti-FLAG antibody was performed with nuclear fractions of H2A3-WT and S40A-mutant mESCs (Fig. 6a and Additional file 1: Figure S3). O-GlcNAcylation on H2AS40 was confirmed in the IP samples of H2A3-WT, but not in S40A mutants, and increased by ETP treatment in H2A3-WT mESCs. In the non-treated cells, AcH2AZ, but not $\gamma \mathrm{H} 2 \mathrm{AX}$, co-precipitated with H2A3-WT (Fig. 6a). At $30 \mathrm{~min}$ after ETP treatment, however, the co-precipitation of AcH2AZ became undetectable. In contrast, $\gamma \mathrm{H} 2 \mathrm{AX}$ started to be co-precipitated with H2A3-WT. Co-precipitation of $\gamma \mathrm{H} 2 \mathrm{AX}$ with H2A3-WT further increased at $4 \mathrm{~h}$ after the treatment. No association of the S40A mutant with AcH2AZ or $\gamma \mathrm{H} 2 \mathrm{AX}$ was detected.

$O$-GlcNAc transferase (Ogt) is the sole enzyme known to catalyze $O$-GlcNAcylation $[3-5,35]$. It is interesting to note that Ogt was co-precipitated only with H2A3WT. The associated Ogt decreased at $30 \mathrm{~min}$ and then increased again at $4 \mathrm{~h}$ after treatment with ETP. These data indicate the physiological interaction among the H2AS40Gc, AcH2AZ, $\gamma \mathrm{H} 2 \mathrm{AX}$, and Ogt during the DDR process. Importantly, the association of H2AS40Gc with $\mathrm{AcH} 2 \mathrm{AZ}$ shifts to the association with $\gamma \mathrm{H} 2 \mathrm{AX}$ by the advancing DDR mechanism.

\section{Discussion}

In this study, the critical finding was that H2AS40Gc accumulated at the restricted narrow area of DNA damage sites, where H2AS40Gc associated with AcH2AZ and then associated with $\gamma \mathrm{H} 2 \mathrm{AX}$ during the DDR process. Compared to H2A3-WT mESCs, S40A-mutant mESCs with lower H2AS40Gc were less resistant to chemicalinduced DNA damage. Furthermore, H2AS40Gc was required for accumulation of DDR factors such as DNAPKcs and Rad51 at the damage site.

A40 to $\mathrm{S} 40$ in $\mathrm{H} 2 \mathrm{~A}$ is a rare mutation in mammals to produce diversity in the nucleosome structure [13]. We found several similarities between S40-type $\mathrm{H} 2 \mathrm{~A}$ and histone $\mathrm{H} 2 \mathrm{~A}$ variants: (i) S40-type $\mathrm{H} 2 \mathrm{~A}$ isoforms susceptible 

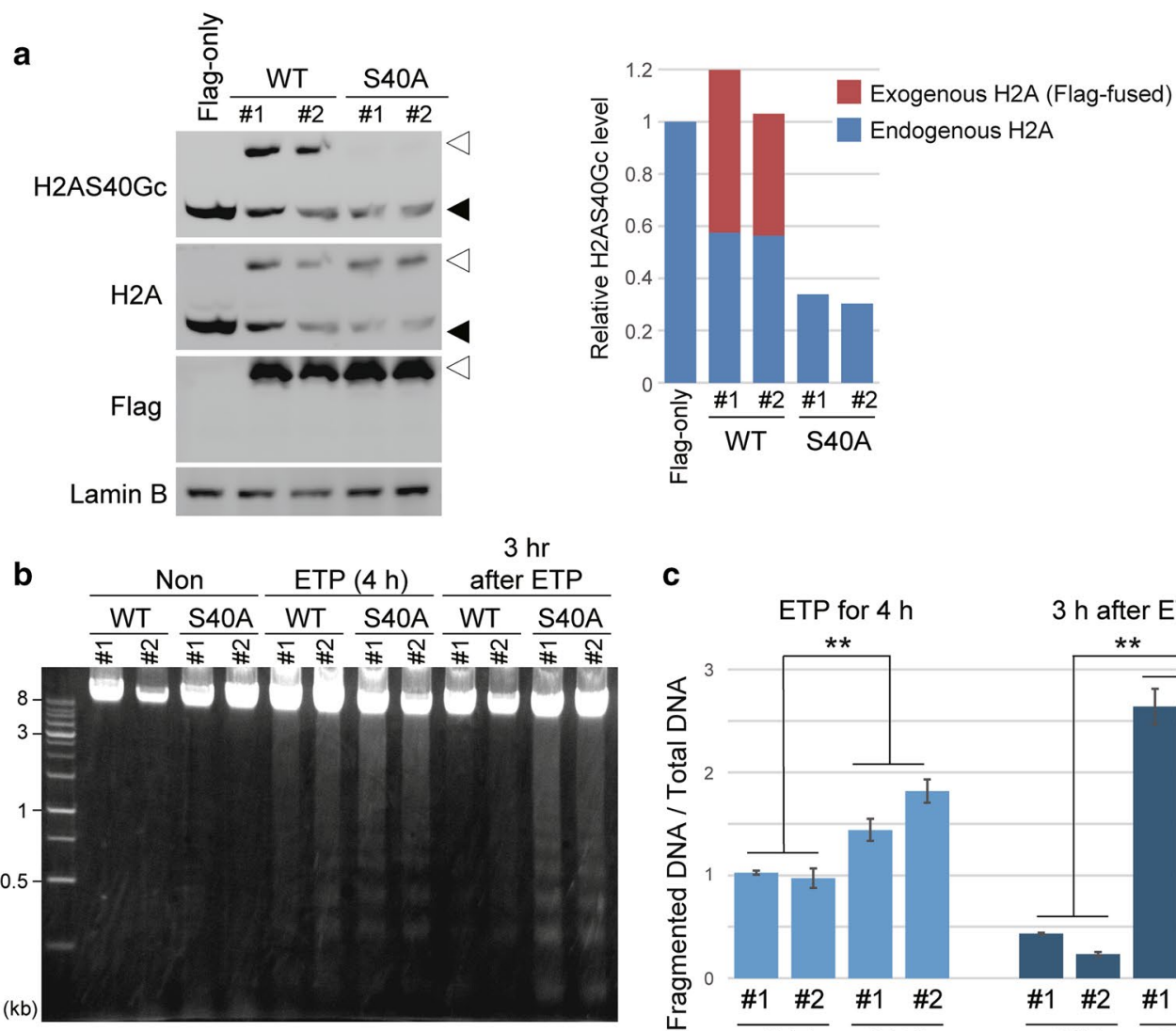

C
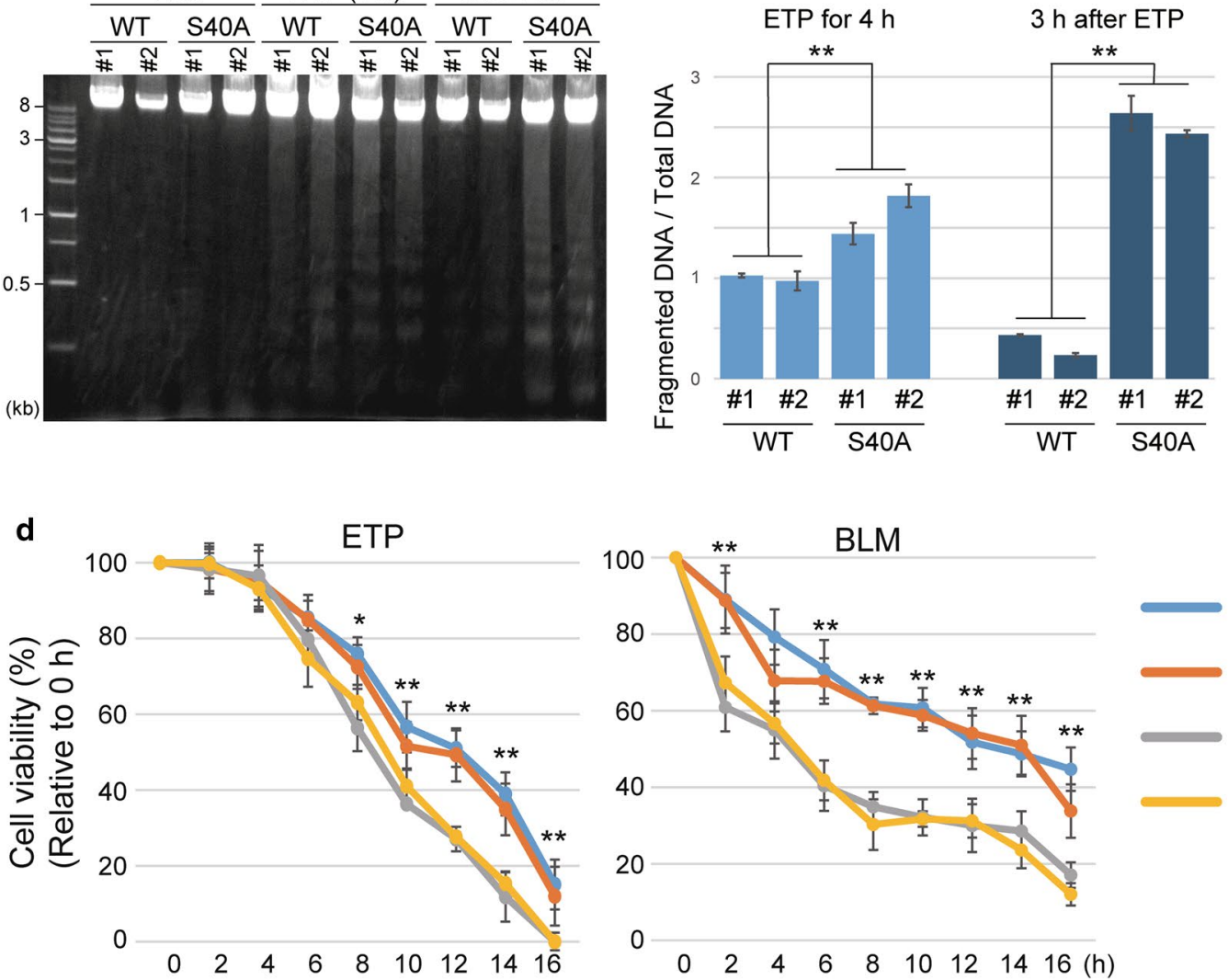

Fig. 4 H2AS4OGC is involved in the DNA damage repair mechanism. a Left, WB analysis in mESC lines stably expressing $3 \times$ FLAG-fused H2A3-WT (WT) or S40A mutant. Lamin B was used as the internal control. Right, bar graph was visualized from the band intensities of endogenous (black arrowhead) and exogenous (white arrowhead) H2AS40Gc calculated by the ImageJ software. Values were normalized by the intensities of Lamin $B$ and expressed as relative to expression of endogenous H2AS40Gc in mESCs expressing Flag-only. $\mathbf{b}$ Electrophoresis image of genomic DNA of H2A3-WT mESCs (WT) and S40A mESCs (S40A-mutant) treated with ETP. c Ratio of the fragmented genomic DNA in H2A3-WT and S40A-mutant mESCs treated with ETP. Bar graph was visualized from intensities of electrophoresis image calculated by the ImageJ software. Values of fragmented genomic DNA were normalized to the intensity of total genomic DNA and expressed as the relative ratio in biological triplicate experiments. ${ }^{* *} p<0.01$ (Student's $t$-test). d Time-course experiments of the viability of mESCs in the presence of ETP and bleomycin (BLM). mESCs stably expressing H2A3-WT and S40A-mutant were used, and cell viabilities were measured by the WST-1 assay. Values were normalized to $0 \mathrm{~h}$ and indicated as mean \pm S.D. $(n=3) .{ }^{* *} p<0.01,{ }^{*} p<0.05$ (Student's t-test, WT \#1 \&\#2 versus S40A \#1 \&\#2) 


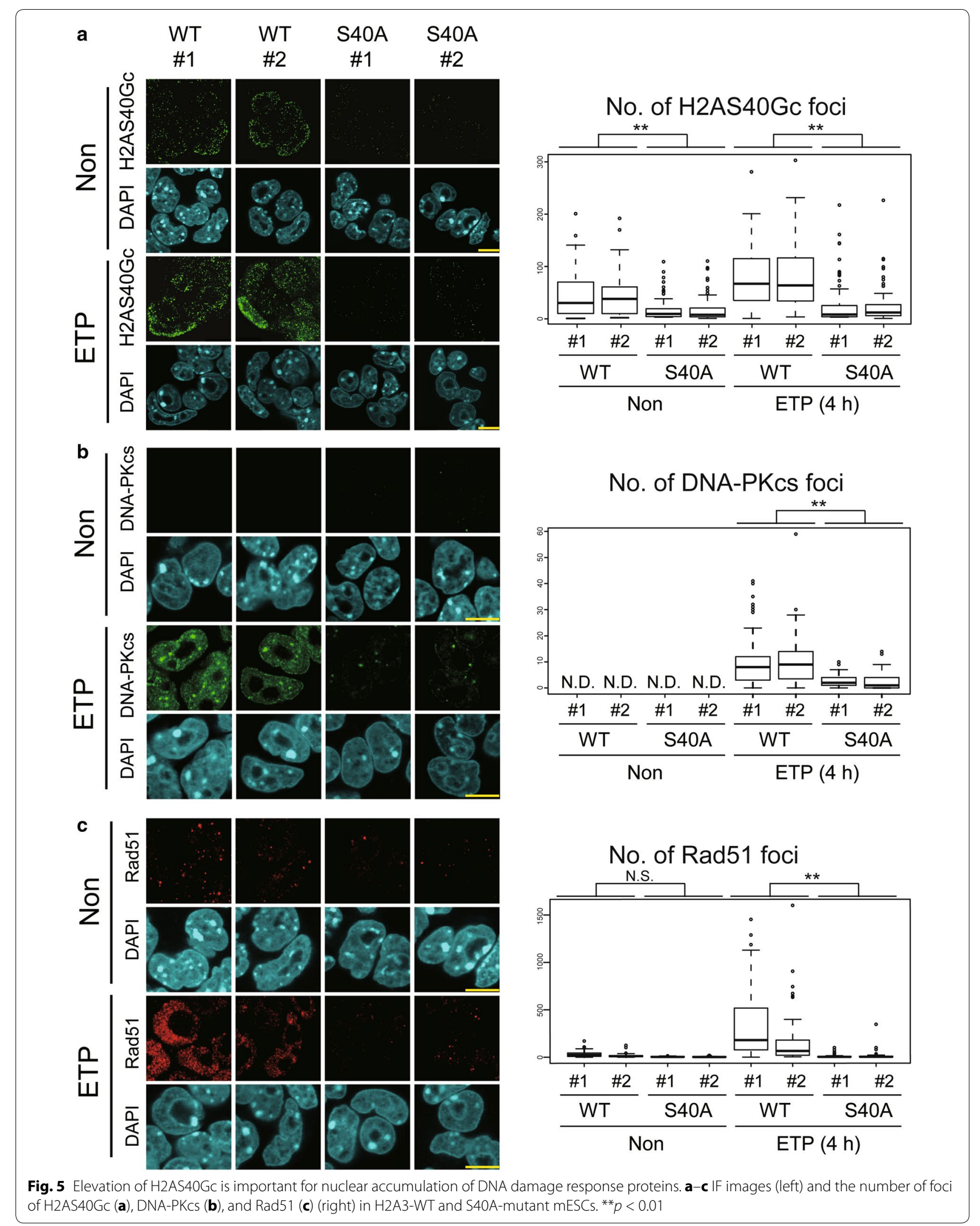




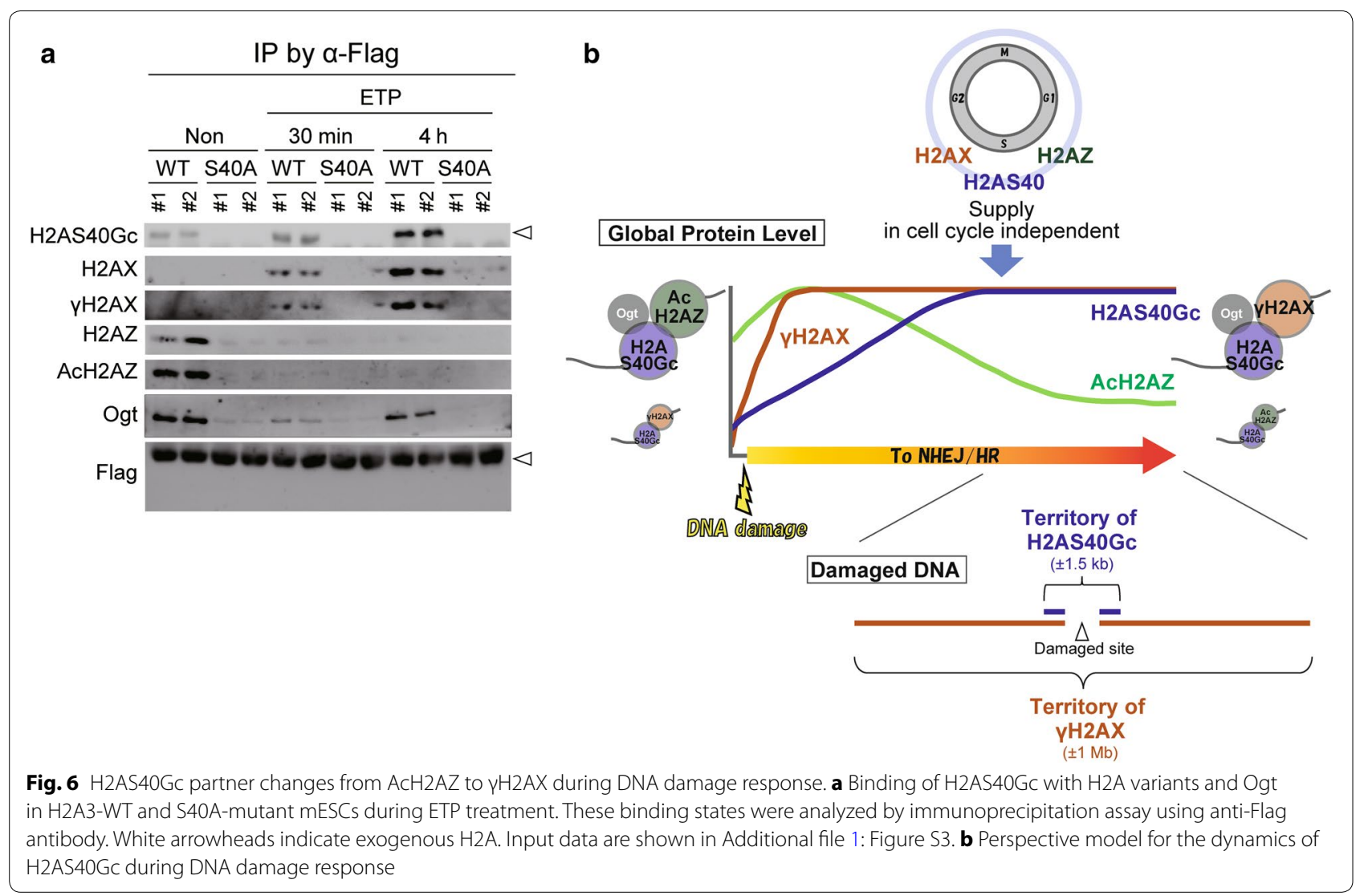

for $O$-GlcNAcylation are produced throughout the cell cycle; (ii) among the S40-type H2A isoforms, Hist3h2a (encoding H2A3) is particularly located as a single gene at the histone gene cluster 3; and (iii) the mRNA of S40type $\mathrm{H} 2 \mathrm{~A}$ isoforms has poly(A) tail structure. Therefore, S40-type $\mathrm{H} 2 \mathrm{~A}$ isoforms, including $\mathrm{H} 2 \mathrm{~A} 3$, are equipped with characteristics similar to those of histone variants such as H2AX and H2AZ. Thus, at least, H2A3 may be considered as a histone variant.

De-condensation of chromatin is required to improve the accessibility of the nucleosomal DNA to the transcriptional and DDR apparatus [36-40]. Nucleosomes containing histone variants lead to profound chromatin alteration and thus influence a multitude of biological processes ranging from transcriptional regulation to genome stability $[15,16,21,22]$. Evolutionary changes in A40-type $\mathrm{H} 2 \mathrm{~A}$ prototype into S40-type and consequent $O$-GlcNAcylation may contribute to the variation in the nucleosome [13]. The findings of the present study indicate that H2AS40Gc, in collaboration with AcH2AZ and $\gamma \mathrm{H} 2 \mathrm{AX}$, works as a component of the DDR apparatus. ChIP-seq analysis of mouse trophoblast stem cells revealed that H2AS40Gc is enriched at the genic loci [13]. In the present study, we induced DNA damage at sites in the genic and intergenic area by using CRISPR/
CAS9 and found that the territory around H2AS40Gc including both genic and intergenic areas is involved in the response to genome damage. Thus, in addition to regulation of gene expression, H2AS40Gc might maintain genome integrity.

In the initial phase of the DDR process, the incorporation of H2AZ into chromatin and its subsequent rapid removal create an open nucleosome structure $[28,29]$, and followed by the continued presence of $\mathrm{H} 2 \mathrm{AX}$ in the chromatin [26, 27]. Previous reports have shown that nucleosomes containing $\mathrm{H} 2 \mathrm{AZ}$ are less stable and that $\mathrm{H} 2 \mathrm{AZ}$ exchange promotes the formation of open, relaxed chromatin in response to DNA damages [28, 29]. In the present study, S40-type H2A3 was co-precipitated with $\mathrm{AcH} 2 \mathrm{AZ}$ before ETP treatment. Structural studies indicate that steric clashes preclude hetero-dimerization of $\mathrm{H} 2 \mathrm{~A}$ and $\mathrm{H} 2 \mathrm{AZ}$ in the same nucleosome [16, 21, 32]. Because the interaction between the two $\mathrm{H} 2 \mathrm{~A}$ proteins in the nucleosome occurs via their L1 domains, H2AS40Gc may be involved in the formation of less stable nucleosomes with $\mathrm{AcH} 2 \mathrm{AZ}$ at DNA damage sites.

In the case of $\gamma \mathrm{H} 2 \mathrm{AX}$, phosphorylation is required for incorporation into the nucleosome at the DNA damage sites [40, 41], whereas H2AZ is acetylated after incorporation into the nucleosome $[42,43]$. Therefore, these 
posttranslational modifications of histones occur before and after incorporation into the nucleosome, depending on the histone modification. Considering the decrease in the association of Ogt with H2A3-WT at the early phase of ETP treatment, H2AS40Gc might be incorporated into the nucleosome after $\mathrm{O}$-GlcNAcylation outside the nucleosome. However, we cannot exclude the possibility of H2AS40 O-GlcNAcylation in nucleosome because Ogt co-localized with H2AS40-WT before ETP treatment. Moreover, the timing and mechanism of O-GlcNAcylation remains to be investigated.

To date, several $O$-GlcNAcylated sites on the serine or threonine of core histones have been reported [6-13]. Recently, O-GlcNAcylation on H2AX at Ser139 (S139) was found in DNA damage foci [44]. It is well established that $\gamma \mathrm{H} 2 \mathrm{AX}$ expands to a mega-base region from the site of DNA damage before completion of the repair process $[24,27]$. Interestingly, the $O-G l c N A c y l a t i o n$ of $\mathrm{H} 2 \mathrm{AX}$ is induced by $\gamma \mathrm{H} 2 \mathrm{AX}$ and seems to act as a negative feedback regulator to limit the expansion of $\gamma \mathrm{H} 2 \mathrm{AX}$ at the site of DNA damage. S139 on H2AX is the phosphorylation site by ATM/ATR/DNA-PKcs [45-48], and competition between $O$-GlcNAcylation and phosphorylation of H2AX has been postulated [44]. Considering the competition theory, H2AS40Gc may affect the level of phosphorylation [3]. In this case, lack of this phosphorylation event caused by $O$-GlcNAcylation may also contribute to the observed phenotype. Alternatively, overexpression of H2A3-WT may also increase the level of S40-phosphorylated H2AS (H2AS40P). Unfortunately, however, the phosphorylation at $\mathrm{S} 40$ of H2AS40-type isoforms has not been identified, and an antibody specific for H2AS40P has not yet been developed. Taken together with the present finding that H2AS40Gc is induced by DNA damage, accumulates in the restricted area $(\sim 1.5 \mathrm{~kb})$ in the vicinity of the induced site of DNA damage, and interacts with $\mathrm{AcH} 2 \mathrm{AZ}$ and $\gamma \mathrm{H} 2 \mathrm{AX}$ during the DDR, we conclude that $\mathrm{H} 2 \mathrm{AS} 40 \mathrm{Gc}$ plays a role in maintaining genome integrity along with $\mathrm{AcH} 2 \mathrm{AZ}$ and $\gamma \mathrm{H} 2 \mathrm{AX}$.

\section{Conclusions}

Here, we propose a model for H2AS40Gc function in the DDR mechanism (Fig. 6b). H2AS40Gc is supplied in response to DNA damages by constant production of S40-type $\mathrm{H} 2 \mathrm{~A}$ and subsequent $O$-GlcNAcylation occurs. H2AS40Gc, AcH2AZ, and $\gamma \mathrm{H} 2 \mathrm{AX}$ are recruited at the DNA damage site. After the occurrence of chemical-induced DNA damage, H2AS40Gc interacts with $\mathrm{AcH} 2 \mathrm{AZ}$ only at the initial phase of DDR process, and after that, H2AS40Gc is bound to $\gamma \mathrm{H} 2 \mathrm{AX}$. Thus, the nucleosome members at the DNA damage site change from $\mathrm{H} 2 \mathrm{AS} 40 \mathrm{Gc} / \mathrm{AcH} 2 \mathrm{AZ}$ to $\mathrm{H} 2 \mathrm{AS} 40 \mathrm{Gc} / \gamma \mathrm{H} 2 \mathrm{AX}$ during the repair process. Occupancy of $\gamma \mathrm{H} 2 \mathrm{AX}$ extends to mega-base limit along the chromatin during the repair process, whereas $\mathrm{H} 2 \mathrm{AS} 40 \mathrm{Gc}$ resides in the restricted area. This accumulation of H2AS40Gc seems to be required to form the foci of DNA repair apparatus such as DNA-PKcs and Rad51. In conclusion, S40-type H2A such as $\mathrm{H} 2 \mathrm{~A} 3$ shows characteristics similar to the histone variants rather than canonical $\mathrm{H} 2 \mathrm{~A}$. The present study suggested that H2AS40Gc functions to maintain the genome integrity through DDR mechanism in association with $\mathrm{AcH} 2 \mathrm{AZ}$ and $\gamma \mathrm{H} 2 \mathrm{AX}$.

\section{Methods \\ Reagents}

Reagents were purchased from Wako Pure Chemicals unless otherwise stated. Camptothecin (CPT), etoposide (ETP), and bleomycin (BLM) (Cayman Chemical) were dissolved in DMSO at concentrations of $20 \mathrm{mM}$, $100 \mathrm{mM}$, and $10 \mathrm{mg} / \mathrm{mL}$, respectively, to make stock solutions and stored at $-20{ }^{\circ} \mathrm{C}$. Primers were purchased from Sigma-Aldrich, Eurofins Genomics, or FASMAC and are listed in Additional file 1: Table S1. Antibodies used in this study are listed in Additional file 1: Table S2.

\section{Cell culture}

The mouse embryonic stem cell (mESCs) line J1, derived from 129S4/SvJae mouse embryos, was kindly provided by $\mathrm{Dr}$. En Li [49]. The mESCs were cultured on a gelatincoated dish (Sigma-Aldrich) in D-MEM (high glucose) supplemented with $15 \% \mathrm{FBS}, 0.1 \mathrm{mM} \beta$-mercaptoethanol, $2 \mathrm{mM}$ L-glutamine, $1 \mathrm{mM}$ Na pyruvate, non-essential amino acids, and $1500 \mathrm{U} / \mathrm{mL}$ LIF (ESGRO; Millipore). For induction of DNA damages, mESCs were cultured in the presence of CPT $(50 \mu \mathrm{M})$ or ETP $(100 \mu \mathrm{M})$ for up to $4 \mathrm{~h}$. Synchronization of mESCs was performed as previously reported [50].

\section{Cell viability assay}

The cell viability after the treatment of ETP and BLM was determined using the cell proliferation reagent WST-1 (Roche). mESCs were plated at $1 \times 10^{4}$ cells/well in 96-well plates in $100 \mu \mathrm{L}$ of culture medium and cultured for $24 \mathrm{~h}$ before use. The medium was changed to new ones containing ETP $(100 \mu \mathrm{M})$ and BLM $(20 \mu \mathrm{g} / \mathrm{mL})$, and mESCs were incubated at $37^{\circ} \mathrm{C}$ for $2-16 \mathrm{~h}$. At the end of the culture, $10 \mu \mathrm{L}$ of WST- 1 was added to each well, and after an incubation for $2 \mathrm{~h}$ at $37^{\circ} \mathrm{C}$, the absorption of each well at $440-655 \mathrm{~nm}$ was measured using a plate reader iMark (Bio-Rad).

\section{Construction of overexpression vectors}

The pENTR/D-TOPO vector-cloned $3 \times$ FLAGonly, $3 \times$ FLAG-fused H2A3-WT, and its serine 40 to alanine 40 mutant (S40A) were subcloned into 
pCAG-DEST-IRES-Puromycin-P2A-Venus-pA vector [2, 13] using Gateway LR Clonase (Invitrogen). For induction of site-specific DNA damage using CRISPR/CAS9, assembly of gRNA cassettes into $\mathrm{pX} 458$ vector (Addgene) was performed using the Golden Gate cloning method as described previously [51]. For construction of nucleasedeficient CAS9, D10 and H840 of CAS9 were mutated into alanine by PCR amplification. The sequences of resulting constructs were confirmed by BigDye sequencing (Applied Biosystems).

\section{Transfection}

mESCs were cultured in six-well plates to 50\% confluence and transfected with $2 \mu \mathrm{g}$ of plasmid DNA using $4 \mu \mathrm{L}$ of jetPRIME (Polyplus) per well. For the establishment of mESCs stably expressing $3 \times$ FLAG-H2A3, cells were replated onto a $10-\mathrm{cm}$ dish at $24 \mathrm{~h}$ after transfection and cultured for a week in the presence of $10 \mu \mathrm{g} / \mathrm{mL}$ puromycin. Puromycin-resistant colonies were transferred individually to a 96-well plate. Cells that expressed the fusion proteins were expanded, collected, frozen in liquid nitrogen, and stored in cell cryopreservation medium (CELLBANKER 1, Takara Bio) at $-80^{\circ} \mathrm{C}$.

\section{Chromatin immunoprecipitation (ChIP) assay}

ChIP assay was performed using ChIP-IT Express Kit (Active Motif) according to the manufacturer's instructions with minor modifications. Briefly, the fixed cells were lysed and chromatin was sheared using an enzymatic shearing cocktail for $10 \mathrm{~min}$ at $37^{\circ} \mathrm{C}$. The sheared chromatin was mixed with $3 \mu \mathrm{g}$ of antibody and $40 \mu \mathrm{L}$ of magnetic beads (Dynabeads M-280 sheep anti-mouse IgG or Dynabeads ProteinG (Invitrogen)) and incubated with rotation at $4{ }^{\circ} \mathrm{C}$ overnight. After IP, DNA was recovered by incubation with elution buffer $(10 \%$ SDS, $300 \mathrm{mM} \mathrm{NaCl}, 10 \mathrm{mM}$ Tris- $\mathrm{HCl}$, and $5 \mathrm{mM}$ EDTA, $\mathrm{pH}$ 8.0) at $65{ }^{\circ} \mathrm{C}$ for $6 \mathrm{~h}$. Recovered DNA was purified using ChIP DNA Clean and Concentration Kit (Zymo Research) and was subjected to ChIP-quantitative PCR (qPCR).

\section{RNA extraction, CDNA synthesis, and genomic DNA extraction}

Total RNA was isolated from cells using Direct-zol RNA Kit (Zymo Research) according to the manufacturer's instructions. First-strand cDNA was synthesized from $1 \mu \mathrm{g}$ of total RNA using SuperScript III (Invitrogen) and oligo $(\mathrm{dT})_{20}$ primer (in Fig. 1d, middle), random hexamer (in Fig. 1d, right), or a mixture of both (in Fig. 1d, left). Genomic DNA was extracted from mESCs treated with CPT or ETP as described previously [52]. To investigate fragmentation status, genomic DNA was subjected to electrophoresis on 1.2\% agarose gel and stained using GelRed (Biotium).

\section{Quantitative PCR}

ChIP-qPCR was performed with KOD SYBR qPCR Mix (Toyobo) using Light Cycler 96 (Roche). PCR was performed with the following thermocycling conditions: denaturation at $95^{\circ} \mathrm{C}$ for 1 min and 40 cycles of denaturation at $95^{\circ} \mathrm{C}$ for $10 \mathrm{~s}$ and elongation at $60^{\circ} \mathrm{C}$ for $30 \mathrm{~s}$. For site-specific DNA damage assay by CRISPR/CAS9, ChIP signals were calculated as ChIP DNA/Input DNA and expressed as fold enrichment relative to the uncut (mESCs expressing guide RNA and nuclease-deficient CAS9).

Gene expression analyses of histone coding genes were performed using a high-throughput gene expression platform based on microfluidic dynamic arrays (BioMark, Fluidigm) as described previously [52]. Results of RTqPCR of histone genes by BioMark were visualized as a heatmap using $\mathrm{MeV}$ software [53]. Statistical analysis was performed using Student's $t$ test.

\section{Immunofluorescence analysis}

Cells cultured in four-well plates were fixed with $4 \%$ paraformaldehyde and permeabilized with $0.2 \%$ Triton X-100 followed by blocking with 5\% BSA (Rockland)-Tween 20-PBS and incubation with the primary antibody overnight at $4{ }^{\circ} \mathrm{C}$. The secondary antibody was added, and incubation was continued for another $1 \mathrm{~h}$ at room temperature. Nuclei were stained with DAPI $(1 \mu \mathrm{g} / \mathrm{mL}$; Dojindo). Fluorescence images were acquired with a confocal microscope FV10i (OLYMPUS). For measurements of foci of H2AS40Gc and DDR-related proteins, merged immunofluorescence images of DAPI and the proteins were processed using CellProfiler software [54]. At least 50 nuclei were used for the measurements per protein. Statistical analysis was performed by Wilcoxon rank sum test.

\section{Western blotting}

Nuclear proteins of each sample were collected using LysoPure Nuclear and a Cytoplasmic Extractor Kit according to the manufacturer's protocols. Proteins were fractionated by $20 \%$ SDS-PAGE (XV PANTERA Gel; DRC), blotted onto PVDF membranes (Immobilon-P, Millipore), and blocked with $5 \%$ skim milk-0.1\% Tween 20-TBS for $1 \mathrm{~h}$ and incubated at $4{ }^{\circ} \mathrm{C}$ overnight with the primary antibody diluted in $1 \%$ BSA-0.1\% Tween 20-TBS. For detection of H2AS40Gc by 20B2, the blotted membrane was blocked with $5 \%$ BSA-0.1\% Tween 20-PBS (blocking buffer) and washed with $0.1 \%$ Tween 20-PBS, and antibody was diluted using blocking buffer. Protein bands were detected using secondary antibody 
conjugated with horseradish peroxidase (Jackson ImmunoResearch), and ImmunoStar Basic or ImmunoStar LD.

\section{Immunoprecipitation}

For the immunoprecipitation of the $3 \times$ FLAG-tagged $\mathrm{H} 2 \mathrm{~A}$ isoforms, nuclear fractions (100 $\mu \mathrm{g}$ each) were mixed with $20 \mu \mathrm{L}$ anti-FLAG M2 Magnetic Beads (Sigma-Aldrich) and incubated with rotation at $4{ }^{\circ} \mathrm{C}$ overnight. Precipitates were washed five times with TBS, and the beads were suspended in Lane Marker Reducing Sample Buffer (Thermo) and boiled to extract proteins.

\section{Additional file}

Additional file 1: Figure S1-S3 and Table S1-S2.

\section{Abbreviations}

O-GlcNAc: O-linked $\beta$-N-acetylglucosamine; H2AS40Gc: O-GICNAc modification at serine 40 of $\mathrm{H} 2 \mathrm{~A}$; $\mathrm{mESC}$ : mouse embryonic stem cell; DDR: DNA damage repair; Ogt: O-GICNAc transferase; CPT: camptothecin; ETP: etoposide; ChIP: chromatin immunoprecipitation.

\section{Authors' contributions}

K.H. and K.S. designed this study. M.H. raised the antibody against H2AS40GC (20B2). R.T. performed the immunofluorescence experiments and image analysis. K.H. and C.Y. constructed the expression vectors and performed the GPCR and cell culture experiments. K.H. performed the all other experiments. K.H., S.T., and K.S. wrote the manuscript. K.H. and M.H. conceived the O-GICNAC project. K.S. supervised the O-GICNAc project. All authors read and approved the final manuscript.

\section{Author details \\ ${ }^{1}$ Laboratory of Cellular Biochemistry, Department of Animal Resource Sci- ences/Veterinary Medical Sciences, The University of Tokyo, Tokyo 113-8657, Japan. ${ }^{2}$ Waseda Research Institute for Science and Engineering, Waseda University, Tokyo 169-8555, Japan.}

\section{Acknowledgements}

We acknowledge Prof. Bruce D. Murphy (Université de Montréal) for reading the manuscript and providing critical comments. We are grateful to Kenta Nishitani and Kanae Terada (The University of Tokyo) for technical assistance. We thank Prof. Hiroshi Nagashima, Dr. Jun Ohgane, and Dr. Yoshikazu Arai (Meiji University) for the use of confocal laser scanning microscope.

\section{Competing interests}

The authors declare that they have no competing interests.

\section{Availability of supporting data}

Not applicable.

\section{Consent for publication}

All authors have consented to publication.

\section{Ethical approval and consent to participate}

Not applicable.

\section{Funding}

This study was supported by the Advanced Research for Medical Products Mining Program of the National Institute of Biomedical Innovation (NIBIO), Japan (to K.S.), and Bio-oriented Technology Research Advancement Institute (BRAIN), Japan (to K.S.), and a Grant-in-Aid for Scientific Research A from the Ministry of Education, Culture, Sports, Science and Technology (MEXT), Japan (No. 26252052, to K.S.), and Lotte Shigemitsu Prize, Japan (to K.H.), and Mizutani Foundation for Glycoscience (to K.S.).

\section{Publisher's Note}

Springer Nature remains neutral with regard to jurisdictional claims in published maps and institutional affiliations.

Received: 25 July 2017 Accepted: 13 October 2017

Published online: 30 October 2017

\section{References}

1. Jang H, Kim TW, Yoon S, Choi SY, Kang TW, Kim SY, Kwon YW, Cho EJ, Youn HD. O-GICNAc regulates pluripotency and reprogramming by directly acting on core components of the pluripotency network. Cell Stem Cell. 2012:11(1):62-74.

2. Hayakawa K, Hirosawa M, Tabei Y, Arai D, Tanaka S, Murakami N, Yagi S, Shiota K. Epigenetic switching by the metabolism-sensing factors in the generation of orexin neurons from mouse embryonic stem cells. J Biol Chem. 2013;288(24):17099-110.

3. Hardivillé $S$, Hart GW. Nutrient regulation of signaling, transcription, and cell physiology by O-GIcNAcylation. Cell Metab. 2014;20(2):208-13.

4. Harwood KR, Hanover JA. Nutrient-driven O-GlcNAc cycling-think globally but act locally. J Cell Sci. 2014;127(Pt 9):1857-67.

5. Nagel AK, Ball LE. O-GlcNAc transferase and O-GlcNAcase: achieving target substrate specificity. Amino Acids. 2014;46(10):2305-16.

6. Sakabe K, Wang Z, Hart GW. Beta-N-acetylglucosamine (O-GICNAc) is part of the histone code. Proc Natl Acad Sci USA. 2010;107(46):19915-20.

7. Zhang S, Roche K, Nasheuer HP, Lowndes NF. Modification of histones by sugar $\beta$-N-acetylglucosamine (GlcNAc) occurs on multiple residues, including histone $\mathrm{H} 3$ serine 10, and is cell cycle-regulated. J Biol Chem. 2011;286(43):37483-95

8. Schouppe D, Ghesquière B, Menschaert G, De Vos WH, Bourque S, Trooskens G, Proost P, Gevaert K, Van Damme EJ. Interac tion of the tobacco lectin with histone proteins. Plant Physiol. 2011;155(3):1091-102.

9. Fujiki R, Hashiba W, Sekine H, Yokoyama A, Chikanishi T, Ito S, Imai Y, Kim J, He HH, Igarashi K, et al. GlcNAcylation of histone H2B facilitates its monoubiquitination. Nature. 2011;480(7378):557-60.

10. Fong JJ, Nguyen BL, Bridger R, Medrano EE, Wells L, Pan S, Sifers RN. $\beta$-N-Acetylglucosamine (O-GlcNAc) is a novel regulator of mitosis-specific phosphorylations on histone H3. J Biol Chem. 2012;287(15):12195-203.

11. Hahne H, Moghaddas Gholami A, Kuster B. Discovery of O-GlcNAc-modified proteins in published large-scale proteome data. Mol Cell Proteomics. 2012:11(10):843-50.

12. Gambetta MC, Müller J. A critical perspective of the diverse roles of O-GlcNAc transferase in chromatin. Chromosoma. 2015;124(4):429-42.

13. Hirosawa M, Hayakawa K, Yoneda C, Arai D, Shiota H, Suzuki T, Tanaka S, Dohmae N, Shiota K. Novel O-GlcNAcylation on Ser(40) of canonical H2A isoforms specific to viviparity. Sci Rep. 2016;6:31785.

14. Marzluff WF, Gongidi P, Woods KR, Jin J, Maltais LJ. The human and mouse replication-dependent histone genes. Genomics. 2002;80(5):487-98.

15. Malik HS, Henikoff S. Phylogenomics of the nucleosome. Nat Struct Biol. 2003;10(11):882-91

16. Bönisch C, Hake SB. Histone H2A variants in nucleosomes and chromatin: more or less stable? Nucleic Acids Res. 2012:40(21):10719-41.

17. Wu RS, Bonner WM. Separation of basal histone synthesis from S-phase histone synthesis in dividing cells. Cell. 1981:27(2 Pt 1):321-30.

18. DeLisle AJ, Graves RA, Marzluff WF, Johnson LF. Regulation of histone mRNA production and stability in serum-stimulated mouse 3T6 fibroblasts. Mol Cell Biol. 1983;3(11):1920-9.

19. Marzluff WF, Wagner EJ, Duronio RJ. Metabolism and regulation of canonical histone mRNAs: life without a poly(A) tail. Nat Rev Genet. 2008;9(11):843-54.

20. Mannironi C, Bonner WM, Hatch CL. H2A.X. a histone isoprotein with a conserved C-terminal sequence, is encoded by a novel mRNA with both DNA replication type and polyA 3 ' processing signals. Nucleic Acids Res. 1989;17(22):9113-26.

21. Henikoff S, Smith MM. Histone variants and epigenetics. Cold Spring Harb Perspect Biol. 2015;7(1):a019364. 
22. Redon C, Pilch D, Rogakou E, Sedelnikova O, Newrock K, Bonner W. Histone H2A variants H2AX and H2AZ. Curr Opin Genet Dev. 2002;12(2):162-9.

23. Rogakou EP, Pilch DR, Orr AH, Ivanova VS, Bonner WM. DNA doublestranded breaks induce histone H2AX phosphorylation on serine 139. J Biol Chem. 1998;273(10):5858-68.

24. Rogakou EP, Boon C, Redon C, Bonner WM. Megabase chromatin domains involved in DNA double-strand breaks in vivo. J Cell Biol. 1999;146(5):905-16.

25. Altaf M, Saksouk N, Côté J. Histone modifications in response to DNA damage. Mutat Res. 2007;618(1-2):81-90.

26. Kim JA, Kruhlak M, Dotiwala F, Nussenzweig A, Haber JE. Heterochromatin is refractory to gamma-H2AX modification in yeast and mammals. J Cell Biol. 2007;178(2):209-18.

27. lacovoni JS, Caron P, Lassadi I, Nicolas E, Massip L, Trouche D, Legube G. High-resolution profiling of gammaH2AX around DNA double strand breaks in the mammalian genome. EMBO J. 2010;29(8):1446-57.

28. Xu Y, Ayrapetov MK, Xu C, Gursoy-Yuzugullu O, Hu Y, Price BD. Histone H2A.Z controls a critical chromatin remodeling step required for DNA double-strand break repair. Mol Cell. 2012;48(5):723-33.

29. Gursoy-Yuzugullu O, Ayrapetov MK, Price BD. Histone chaperone Anp32e removes H2A.Z from DNA double-strand breaks and promotes nucleosome reorganization and DNA repair. Proc Natl Acad Sci USA. 2015;112(24):7507-12.

30. Arents G, Burlingame RW, Wang BC, Love WE, Moudrianakis EN. The nucleosomal core histone octamer at 3.1 A resolution: a tripartite protein assembly and a left-handed superhelix. Proc Natl Acad Sci USA. 1991;88(22):10148-52.

31. Luger K, Mäder AW, Richmond RK, Sargent DF, Richmond TJ. Crystal structure of the nucleosome core particle at $2.8 \mathrm{~A}$ resolution. Nature. 1997;389(6648):251-60.

32. Suto RK, Clarkson MJ, Tremethick DJ, Luger K. Crystal structure of a nucleosome core particle containing the variant histone H2A.Z. Nat Struct Biol. 2000;7(12):1121-4.

33. Jackson SP, Bartek J. The DNA-damage response in human biology and disease. Nature. 2009;461(7267):1071-8.

34. Ciccia A, Elledge SJ. The DNA damage response: making it safe to play with knives. Mol Cell. 2010;40(2):179-204.

35. Haltiwanger RS, Blomberg MA, Hart GW. Glycosylation of nuclear and cytoplasmic proteins. Purification and characterization of a uridine diphospho- $N$-acetylglucosamine:polypeptide beta- $N$-acetylglucosaminyltransferase. J Biol Chem. 1992;267(13):9005-13.

36. Kouzarides T. Chromatin modifications and their function. Cell. 2007;128(4):693-705.

37. Cockerill PN. Structure and function of active chromatin and DNase I hypersensitive sites. FEBS J. 2011;278(13):2182-210.

38. Hu G, Cui K, Northrup D, Liu C, Wang C, Tang Q, Ge K, Levens D, CraneRobinson C, Zhao K. H2A.Z facilitates access of active and repressive complexes to chromatin in embryonic stem cell self-renewal and differentiation. Cell Stem Cell. 2013;12(2):180-92.

39. Bakkenist CJ, Kastan MB. Chromatin perturbations during the DNA damage response in higher eukaryotes. DNA Repair (Amst). 2015;36:8-12.

40. Li A, Yu Y, Lee SC, Ishibashi T, Lees-Miller SP, Ausió J. Phosphorylation of histone H2A.X by DNA-dependent protein kinase is not affected by core histone acetylation, but it alters nucleosome stability and histone H1 binding. J Biol Chem. 2010;285(23):17778-88.
41. Heo K, Kim H, Choi SH, Choi J, Kim K, Gu J, Lieber MR, Yang AS, An W. FACT-mediated exchange of histone variant $\mathrm{H} 2 \mathrm{AX}$ regulated by phosphorylation of H2AX and ADP-ribosylation of Spt16. Mol Cell. 2008;30(1):86-97.

42. Babiarz JE, Halley JE, Rine J. Telomeric heterochromatin boundaries require NuA4-dependent acetylation of histone variant H2A.Z in Saccharomyces cerevisiae. Genes Dev. 2006;20(6):700-10.

43. Keogh MC, Mennella TA, Sawa C, Berthelet S, Krogan NJ, Wolek A, Podolny V, Carpenter LR, Greenblatt JF, Baetz K, et al. The Saccharomyces cerevisiae histone H2A variant Htz1 is acetylated by NuA4. Genes Dev. 2006;20(6):660-5.

44. Chen $Q, Y u$ X. OGT restrains the expansion of DNA damage signaling. Nucleic Acids Res. 2016;44(19):9266-78.

45. Burma S, Chen BP, Murphy M, Kurimasa A, Chen DJ. ATM phosphorylates histone H2AX in response to DNA double-strand breaks. J Biol Chem. 2001;276(45):42462-7.

46. Ward IM, Chen J. Histone H2AX is phosphorylated in an ATRdependent manner in response to replicational stress. J Biol Chem. 2001;276(51):47759-62.

47. Stiff T, O'Driscoll M, Rief N, Iwabuchi K, Löbrich M, Jeggo PA. ATM and DNA-PK function redundantly to phosphorylate $\mathrm{H} 2 \mathrm{AX}$ after exposure to ionizing radiation. Cancer Res. 2004;64(7):2390-6.

48. Reitsema T, Klokov D, Banáth JP, Olive PL. DNA-PK is responsible for enhanced phosphorylation of histone $\mathrm{H} 2 \mathrm{AX}$ under hypertonic conditions. DNA Repair (Amst). 2005;4(10):1172-81.

49. Li E, Bestor TH, Jaenisch R. Targeted mutation of the DNA methyltransferase gene results in embryonic lethality. Cell. 1992;69:915-26.

50. Ballabeni A, Park IH, Zhao R, Wang W, Lerou PH, Daley GQ, Kirschner MW. Cell cycle adaptations of embryonic stem cells. Proc Natl Acad Sci U S A. 2011;108(48):19252-7.

51. Sakuma T, Nishikawa A, Kume S, Chayama K, Yamamoto T. Multiplex genome engineering in human cells using all-in-one CRISPR/Cas9 vector system. Sci Rep. 2014;4:5400.

52. Hayakawa K, Ohgane J, Tanaka S, Yagi S, Shiota K. Oocyte-specific linker histone $\mathrm{H} 1 \mathrm{foO}$ is an epigenomic modulator that decondenses chromatin and impairs pluripotency. Epigenetics. 2012;7(9):1029-36.

53. Chu VT, Gottardo R, Raftery AE, Bumgarner RE, Yeung KY. MeV + R: using MeV as a graphical user interface for Bioconductor applications in microarray analysis. Genome Biol. 2008;9(7):R118.

54. Carpenter $A E$, Jones TR, Lamprecht MR, Clarke C, Kang IH, Friman O, Guertin DA, Chang JH, Lindquist RA, Moffat J, et al. Cell Profiler: image analysis software for identifying and quantifying cell phenotypes. Genome Biol. 2006;7(10):R100.

\section{Submit your next manuscript to BioMed Central and we will help you at every step:}

- We accept pre-submission inquiries

- Our selector tool helps you to find the most relevant journal

- We provide round the clock customer support

- Convenient online submission

- Thorough peer review

- Inclusion in PubMed and all major indexing services

- Maximum visibility for your research

Submit your manuscript at www.biomedcentral.com/submit 